\title{
PENGARUH PEMBERIAN BEBERAPA JENIS BAHAN ORGANIK TERHADAP STABILITAS AGREGAT TANAH ULTISOL LIMAU MANIS
}

\author{
Yulnafatmawita, Adrinal, dan Anita Febriani Daulay \\ Laboratorium Fisika Tanah Fakultas Pertanian Universitas Andalas
}

\begin{abstract}
A field research about the effect of some sources of organic matter on aggregate stability of Ultisol was conducted in Limau Manis Padang. The research was aimed to investigate the contribution of different sources of organic matter to soil aggregate stability. Field research was arranged in Completely Randomized Block Design (RBD) consisting of 4 treatments (types of organic matter) and 3 replications (blocks). The treatments were : $\mathrm{A}=$ Tithonia diversifolia, $\mathrm{B}=$ Straw of Oryza sativa, $\mathrm{C}=$ Imperata cylindrica, and $\mathrm{D}=$ Leucaena glauca. The dosage for each treatment was 20 ton/ha based on dry weight. The result showed that Tithonia diversifolia gave the best contribution in improving soil aggregate stability of Ultisol Limau Manis for the first three (3) months.
\end{abstract}

Keywords : organic matter, aggregate stability, marginal soil.

\section{PENDAHULUAN}

Ultisol merupakan salah satu tanah marginal yang mendominasi lahan kering di Indonesia, yang tersebar di Sumatra, Kalimantan, Sulawesi dan Irian Jaya (Hardjowigeno, 1993). Luas Ultisols di Indonesia mencapai 45.8 juta ha atau $24.3 \%$ luas lahan Indonesia (Subagyo et al., 2000). Di Sumatra Barat, Ultisol banyak tersebar di berbagai daerah, salah satunya di Kota Padang seperti tanah di Kebun Percobaan Fakultas Pertanian Limau Manis Padang. Jenis Ultisol didaerah ini termasuk sub ordo Udults dan sub group Orthoxic Tropudults (Imbang, et al., 1994). Udults adalah salah satu sub group dari Ultisol, yang mempunyai rejim kelembaban tanah udik, pada iklim humid, drainase baik dengan curah hujan cukup dan terdapat pada epipedon okrik diatas horizon argilik atau horizon kandik (Fiantis, 2004).

Ultisol mempunyai produktivitas rendah. Hal ini disebabkan bukan saja oleh sifat kimianya yang jelek, tetapi juga akibat ciri biologi dan fisika yang kurang menguntungkan. Diantara sifat fisikanya yang sangat berbahaya yaitu rendahnya stabilitas aggregat tanah. Hal ini akan mengakibatkan mudahnya struktur tanah hancur oleh energi kinetik curah hujan. Aggregat yang hancur atau butir tunggal tanah akan menyumbat pori tanah, sehingga laju infiltrasi rendah dari laju curah hujan. Limau Manis yang terletak di daerah lereng atau kaki G. Gadut mempunyai curah hujan yang cukup tinggi pertahunnya, sehingga kondisi yang demikian akan mudah menimbulkan runoff dan erosi.

Pemanfaatan Ultisols secara terus menerus untuk lahan pertanian, terutama pertanian semusim, tanpa mengindahkan kaidah konservasi, akan mengakibatkan penurunan produktifitas tanah tersebut. Hal ini disebabkan karena kebiasaan petani yang mengolah tanah secara intensif dan membakar sisa tanaman dalam persiapan lahan pertanaman. Kebiasaan demikian mengakibatkan habisnya BO tanah. Bahan organik diketahui merupakan salah satu agen pengikat butir dan pemantap aggregat tanah. Aggregat atau struktur tanah akan mempengaruhi sifat-sifat fisik tanah lainnya yang menunjang pertumbuhan tanaman.

Tanah dengan kandungan $\mathrm{BO}$ yang cukup biasanya akan mempunyai aggregat tanah yang remah dan mantap. Selanjutnya, BO juga mampu menciptakan ruang pori yang seimbang antara pori makro dan mikro untuk transmissi dan retensi air, serta aerase dan drainase tanah yang baik. Tanah yang demikian sangat diharapkan sebagai media tumbuh bagi tanaman. Hal ini disebabkan karena akar dapat berkembang sempurna, aktifitas mikroba tanah dalam perombakan bahan organic untuk menyediakan hara dan 
penguraian zat berbahaya bisa intensif, serta infiltrasi menjadi lancar dan runoff dapat diatasi. Oleh sebab itu, Ultisol bisa memberikan produksi yang memuaskan dan berwawasan lingkungan jika dikelola dengan tepat, sesuai kaidah konservasi tanah terutama BO nya.

Nedrawati (2006) menjelaskan bahwa setelah 3 bulan pemberian bokasi titonia sebagai bahan organik dapat memperbaiki sifat-sifat fisika tanah Ultisol Limau Manis, sehingga terjadinya peningkatan bahan organik dari 3,48\% menjadi $4,22 \%$, serta penurunan BV dari $0,96 \mathrm{gr} / \mathrm{cm}^{3}$ menjadi $0,82 \mathrm{gr} / \mathrm{cm}^{3}$ dan peningkatan total ruang pori (TRP) dari $62,4 \%$ menjadi $68,8 \%$.

Di samping titonia (Tithonia diversifolia), ada beberapa sumber BO lain yang bisa dimanfaatkann jika di suatu daerah titonia tidak ditemukan atau tidak tumbuh. Bahan organik yang banyak dijumpai diantaranya yaitu jerami padi (Oryza sativa), alang-alang (Imperata cylindrica), petai cina (Leucaena glauca), sesbania (Sesbania sp), krinyuh (Colopogonium odorata), gliricidia (Gliricidia, sp), dan lain sebagainya. Bahan organik ini bisa didapatkan dengan mudah dan tanpa biaya di sekitar lahan pertanian. Akan tetapi, apakah efek sumber BO ini bisa menyamai sumber $\mathrm{BO}$ dari titonia perlu dipelajari.

Berdasarkan uraian di atas telah dilakukan penelitian dengan judul "Pengaruh Pemberian Beberapa Jenis Bahan Organik Terhadap Stabilitas Agregat Tanah Ultisol Limau Manis". Penelitian ini bertujuan untuk mempelajari pengaruh beberapa macam BO terhadap stabilitas aggregat tanah.

\section{METODE PENELITIAN}

Percobaan dilakukan pada tanah Ultisol (Tropudult) di Kebun Percobaan $( \pm$ $272 \mathrm{~m}$ dpl) Fakultas Pertanian Universitas Andalas Padang pada bulan AgustusNovember 2006. Empat macam BO yang ditambahkan yaitu tithonia (Tithonia diversifolia), jerami padi (Oryza sativa), alang-alang (Imperata cylindrica), dan petai cina (Laucena glauca sp) sebanyak masingmasing 20 ton/ha berdasarkan berat kering. Bahan organik yang sudah dipotong-potong dicampur dengan tanah saat pengolahan tanah, lalu dibiarkan pada kondisi lapangan. Analisis stabilitas aggregat tanah (metoda ayakan basah dan kering) dilakukan setiap bulan selama 3 bulan di Laboratorium Tanah Lembaga Penelitian Tanah Bogor. Sifat fisika tanah lainnya dianalisis di Laboratorium Jurusan Tanah Fakultas Pertanian Universitas Andalas Padang.

\section{HASIL DAN PEMBAHASAN}

1. Sifat Fisika Tanah Sebelum Penambahan Bahan Organik

Hasil analisis beberapa sifat fisika tanah sebelum perlakuan, baik sebelum maupun sesudah pengolahan tanah, dapat dilihat pada Tabel 1. Dari data yang disajikan, secara umum tidak terdapat adanya perbedaan kriteria sifat fisika tanah akibat pengolahan, kecuali permeabilitas dan indeks kemantapan aggregat tanah.

Peningkatan nilai permeabilitas tanah dari sedang menjadi agak tinggi setelah pengolahan disebabkan oleh kondisi tanah yang semakin poros setelah penglahan. Pengolahan tanah menimbulkan peningkatan volume tanah dalam satuan berat tanah yang sama, hal ini berarti volume tanah yang diisi pori menjadi lebih banyak dibanding sebelum pengolahan. Pada proses awal pengolahan, biasanya pori tanah yang terbentuk lebih banyak berukuran makro yang diisi oleh udara. Pada kondisi jenuh air, pori makro akan melewatkan lebih banyak air dibanding pori mikro.

Kandungan bahan organik tanah awal walaupun termasuk kriteria sama (rendah) persentasenya setelah pengolahan mengalami peningkatan dari kondisi tanah sebelum diolah sebanyak $0.3 \%$. Jika dikonversi ke dalam tanah seluas satu hektar sedalam $20 \mathrm{~cm}$ dengan BV 1.04-1.06 $\mathrm{g} \mathrm{cm}^{-3}$, maka jumlah penambahan ini cukup banyak, yaitu mencapai $6.24-6.36$ ton

Tabel 1. Hasil analisis sifat fisika tanah sebelum pemberian bahan organik (sebelum dan sesudah diolah) 


\begin{tabular}{lccrc}
\hline \multicolumn{1}{c}{ Parameter } & $\begin{array}{c}\text { Sebelum } \\
\text { diolah }\end{array}$ & Kriteria*) & $\begin{array}{r}\text { Sesudah } \\
\text { diolah }\end{array}$ & Kriteria*) \\
\hline Bahan organic $(\%)$ & 2,90 & Rendah & 3,20 & Rendah \\
BV $\left(\mathrm{gcm}^{-3}\right)$ & 1,06 & Sedang & 1,04 & Sedang \\
Permeabilitas (cmjam $\left.{ }^{-1}\right)$ & 4,30 & sedang & 7,30 & Agak cepat \\
TRP (\% vol.) & 59.10 & Sedang & 59,80 & Sedang \\
PDC (\% vol.) & 2,95 & Rendah & 2,20 & Rendah \\
PD L (\% vol.) & 11,22 & Rendah & 2,20 & Rendah \\
PAT (\% vol.) & 23,20 & Tinggi & 23,80 & Tinggi \\
Agregasi $(\%)$ & 44,10 & Kurang & 43,40 & Kurang stabil \\
\hline
\end{tabular}

*) Sumber: Staf Pusat Penelitian Tanah (1983 dalam Hardjowigeno, 2003)

BO kering. Hal ini terjadi akibat adanya sisa tanaman atau vegetasi yang ada di permukaan tanah mengalami dekomposisi, sehingga bahan organik meningkat. Adanya pengaruh pengolahan tanah mempengaruhi proses dekomposisi dalam tanah, sehingga bahan organik yang ada didalam tanah bertambah, seperti yang ditegaskan Yulnafatmawita (2004), bahwa kondisi fisika tanah yang berubah akibat pengolahan menyebabkan kandungan bahan organik tersebut akan berubah juga.

Selanjutnya, jika dilihat secara umum kualitas fisika tanah Ultisol Limau Manis (Tropudult) ini termasuk rendah. Kandungan BO tanah rendah, pori drainase cepat atau pori makro yang bisanya diisi oleh udara juga rendah, serta serta persen aggregasinya kurang dari 50\%. Bila dilihat dari $\mathrm{BV}$ tanah yang berkisar $1.0 \mathrm{gcm}^{-3}$, maka tanah ini mempunyai kandungan liat yang tinggi. Seperti yang diperoleh dari hasil penelitian sebelumnya bahwa tanah ini bertekstur liat (Imbang et al, 1994 dan Fitrisia, 2004). Tanah dengan kandungan liat yang tinggi juga membutuhkan $\mathrm{BO}$ yang cukup banyak untuk memantapkan aggregate tanahnya. Di samping itu, BO juga diharapkan dapat meningkatkan prosentase pori makro tanah yang bisa meningkatkan laju infiltrasi.
Akan tetapi, kandungan BO tanah termasuk criteria rendah. Selanjutnya, pori drainase cepat dan pori drainase lambat atau pori tanah yang berukuran $>8.6 \mu \mathrm{m}$ lebih rendah (hanya $14.17 \%$ sebelum diolah dan $4.40 \%$ setelah diolah) dibanding pori berukuran $<2 \mu \mathrm{m}$. Jadi pada tanah ini pori tanah didominasi oleh pori mikro atau pori tanah berukuran $<2 \mu \mathrm{m}$ yaitu sebanyak $21.73 \%$ sampai $31.60 \%$ total volume atau $37-53 \%$ dari total pori tanah. Oleh sebab itu, pada daerah Limau Manis dengan curah hujan yang cukup tinggi pertahunnya (> $3500 \mathrm{~mm}$ ) sangat memungkinkan laju curah hujan lebih besar dari laju infiltrasi untuk kondisi tanah yang didominasi pori mikro seperti diatas.

\section{Sifat Fisika Tanah Setelah Penambahan Bahan Organik}

Beberapa sifat fisika dan kimia tanah yang dianalisis setelah pemberian bahan organik adalah kandungan bahan organik dan stabilitas agregat.

Kandungan Bahan Organik

Pengaruh pemberian beberapa jenis bahan organik terhadap kandungan bahan organik Tropudults Limau Manis dapat dilihat pada Grafik 1 dibawah ini: 


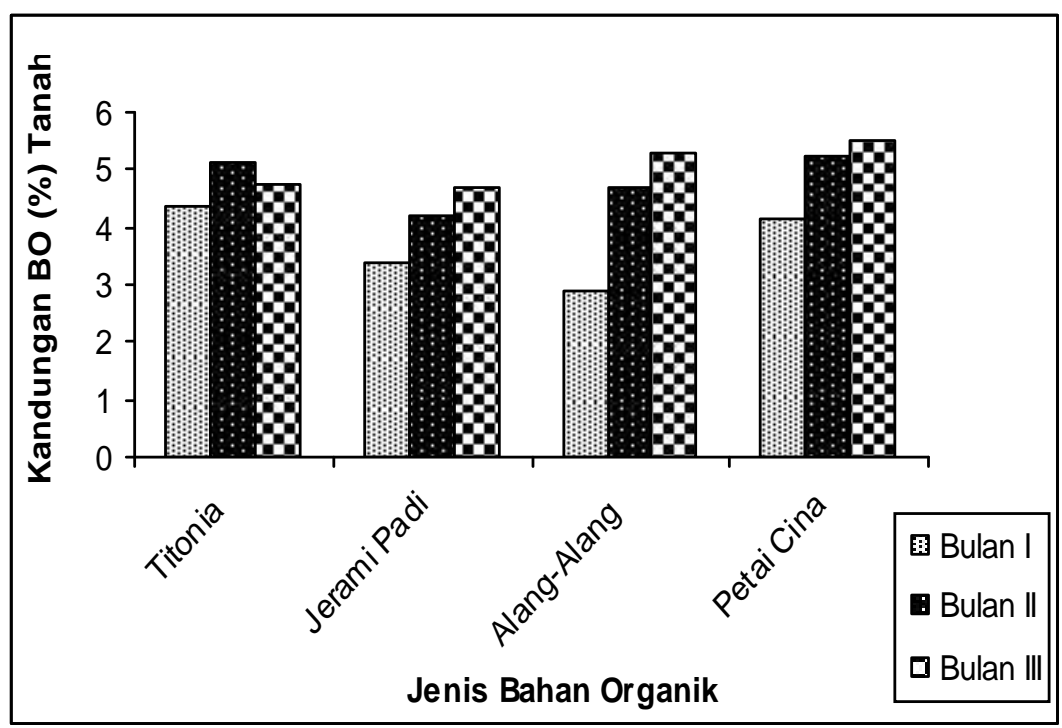

Grafik 1. Pengaruh pemberian beberapa jenis BO terhadap kandungan BO tanah Tropudult Limau Manis

Berdasarkan Grafik 1. diperoleh bahwa, secara umum pemberian semua jenis BO dapat meningkatkan kandungan $\mathrm{BO}$ Ultisol Limau Manis. Hal ini disebabkan karena sumber dari BO tanah pada umumnya berasal dari BO yang ditambahkan ke dalam tanah. Bahan organik yang berasal dari tanah itu sendiri tidak mampu meningkatkan kandungannya, karena laju dekomposisi cendrung lebih tinggi atau paling baik menyamai laju penambahannya. Hal ini didukung oleh iklim tropis basah (suhu dan kelembaban tinggi) yang sangat kondusif bagi aktifitas mikroorganisme tanah dalam merombak BO.

Selanjutnya, terjadi peningkatan kandungan BO tanah setiap bulannya, mulai dari bulan pertama sampai bulan ke tiga setelah applikasi BO, kecuali kandungan BO tanah yang diberi titonia. Kandungan BO tanah meningkat setiap bulannya sampai bulan kedua, akan tetapi cendrung menurun pada bulan ketiga. Hal ini disebabkan karena sifat titonia yang cepat dan mudah melapuk atau terurai, sehingga pada bulan ketiga kandungan $\mathrm{BO}$ tanah sudah mengalami mineralisasi. Cepatnya laju pelapukan titonia didukung oleh kandungan air dan nitrogen $(\mathrm{N})$ yang tinggi atau nilai $\mathrm{C} / \mathrm{N}$ bahan yang rendah. Berdasarkan Jama et al (2000), kandungan $\mathrm{N}$ daun tanaman titonia bisa mencapai $3.5-4 \%$ bobot keringnya. Mikroba membutuhkan $\mathrm{N}$ untuk mensintesis protein dalam membentuk dirinya sendiri.

Pada satu bulan setelah perlakuan, kandungan bahan organic titonia mengalami peningkatan tertinggi dibandingkan perlakuan lain yakni sebanyak $1,70 \%$, pada bulan kedua sekitar $1.82 \%$, dan bulan ketiga hanya $0.19 \%$ dibanding control atau pada bulan ketiga kandungan BO tanah sudah $0.36 \%$ di bawah bulan ke dua. Setelah titonia, peningkatan $\mathrm{BO}$ tanah tertinggi diikuti oleh pemberian petai cina $(1,5 \%)$, jerami padi $(0.8 \%)$, dan alang-alang $(0.3 \%)$ pada bulan pertama. Akan tetapi, kandungan BO tanah yang diberi petai cina cendrung melandai peningkatannya pada bulan ketiga. Hal ini diduga karena kandungan kimia petai cina yang tidak banyak mengandung lignin seperti jerami padi dan alang-alang sehingga lebih mudah melapuk. Sedangkan jerami dan alang-alang masih terlihat kecendrungan meningkat dengan waktu kandungan BO tanahnya.

\section{Persentase Agregat}

Rata-rata nilai persentase agregat Tropults Limau Manis setelah pemberian beberapa jenis bahan organik selama 3 bulan dapat dilihat pada Grafik 2 dibawah ini. 


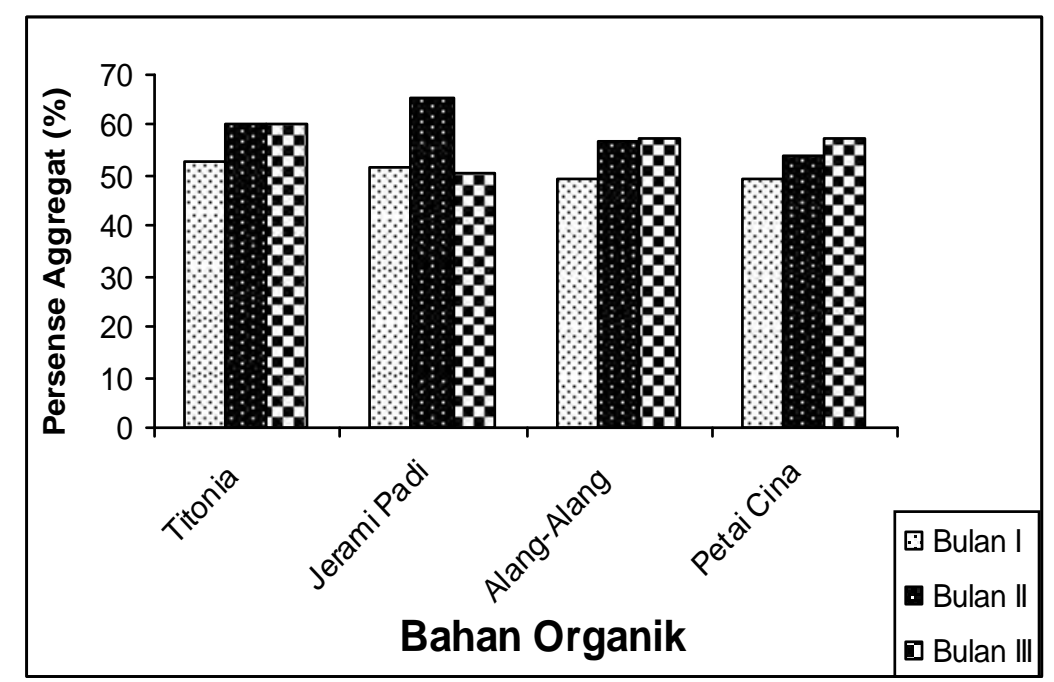

Gambar 2. Pengaruh pemberian beberapa jenis BO terhadap persentase aggregat Tropudult Limau Manis.

Pada Grafik 2. dapat kita lihat bahwa setelah pemberian bahan organic nilai prosentase agregat tanah pada bulan pertama belum merubah persen aggregasi dari kurang menjadi cukup stabil, kecuali pemberian titonia dan jerami padi. Hal ini diduga oleh karena BO belum berfungsi maksimal menggabungkan aggregate tanah dalam jangka satu bulan dari applikasi.

Dua bulan setelah pemberian bahan organik persen aggregasi tanah mengalami peningkatan dibandingkan bulan pertama. Kriteria aggregasi juga berubah dari kurang stabil pada waktu sebelum pemberian BO menjadi cukup stabil. Perlakuan jerami padi merupakan perlakuan yang paling besar mengalami peningkatan persentase agregat (13.4\%) dibandingkan perlakuan lainnya. Hal ini terjadi karena seiring dengan meningkatnya jumlah kandungan bahan organic di dalam tanah.

Akan tetapi, pada bulan ketiga, persen aggregasi tanah cendrung melandai, bahkan pada jerami padi terlihat penurunan. Tidak berubahnya persen aggregasi tanah khusus yang diberi titonia disebabkan oleh menurunnya kandungan BO tanah pada bulan ke tiga ini (Gambar 1). Bahan organic diyakini mampu mengikat butir tunggal atau domain tanah membentuk mikro dan makro aggregate. Sedangkan pelandaian kenaikan BO tanah $(0.47 \%)$ yang diberi jerami menurunkan persen aggregasi tanah sampai $6.5 \%$.

\section{Indeks Kemantapan Agregat}

Rata-rata indeks kemantapan agregat tanah setelah pemberian beberapa jenis bahan organik adalah sebagai berikut dapat dilihat pada Gambar 3.

Grafik 3. Menggambarkan terjadinya perbaikan indeks kemantapan agregat pada bulan pertama, kedua, dan ketiga setelah applikasi bahan organic. Hal ini sejalan dengan tingkat pelapukan BO yang ditambahkan dan proses humifikasi yang terjadi. Kandungan bahan organic tanah sepeti Gambar 1 meningkat dengan waktu sampai 3 bulan setelah aplikasi. Pelapukan BO di samping menghasilkan bahan mineral dan senyawa sederhana, juga menghasilkan humus yang bersifat koloid yang sangat berperan berperan sebagai agen pengikat butir-butir tanah. Sesuai dengan yang diperoleh Yulnafatmawita (2006) bahwa stabilitas aggregate tanah meningkat dengan peningkatan kandungan $\mathrm{BO}$ tanah.

Diantara ke empat jenis BO yang ditambahkan, titonia memberikan kemantapan aggregat yang paling tinggi pada tiap bulan pengamatan sampai bulan ke tiga setelah applikasi. Hal ini merupakan indikasi bahwa titonia dapat digunakan sebagai bahan pemantap aggregat tanah 


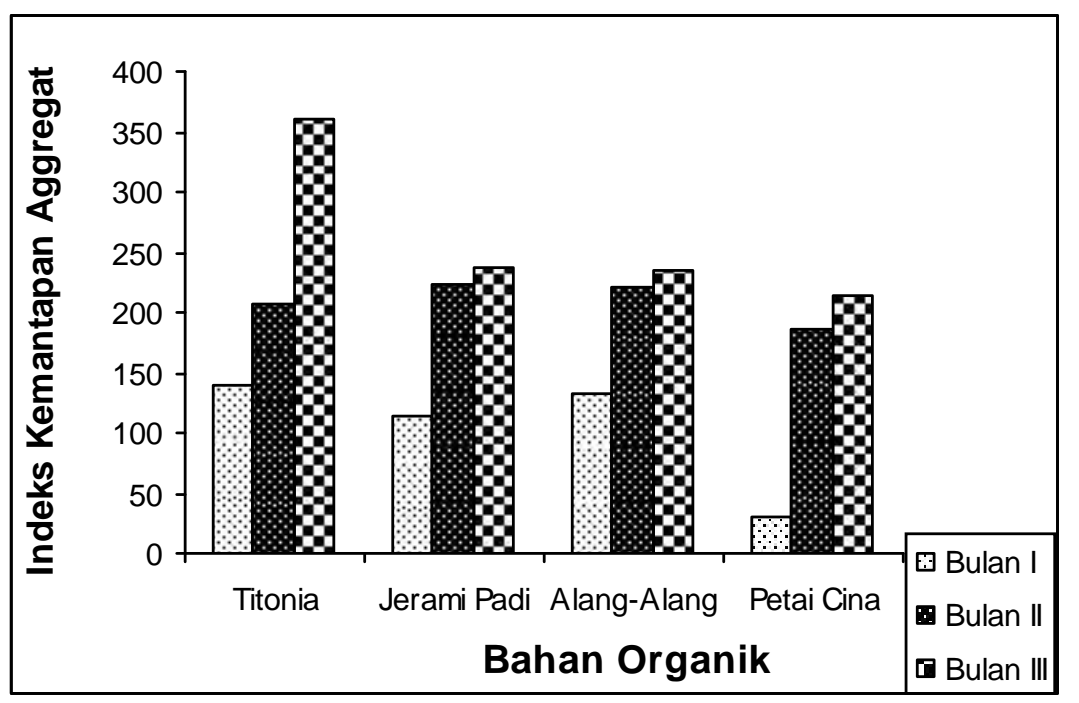

Grafik 3. Rata-rata pemberian beberapa jenis bahan organik terhadap indeks kemantapan agregat Tropudults Limau Manis

terpenting selama musim tanam muda atau selama 3 bulan. Hal ini diduga karena kandungan $\mathrm{N}$ titonia yang tinggi menyebabkan banyaknya mikroba yang terbentuk sehingga proses pelapukan berjalan cepat. Pelapukan yang lanjut akan menghasilkan humus, senyawa yang berperan sebagai aggregator utama.

Jerami padi dan alang-alang terlihat memberikan kontribusi yang berbeda tidak nyata terhadap indeks kemantapan aggregat tanah. Pada bulan pertama ke bulan kedua terjadi peningkatan kemantapan aggregat yang tajam, kemudian melandai dari bulan ke dua ke bulan ke tiga. Hal ini diduga karena proses pelapukan ke dua jenis BO ini yang belum sempurna, berbeda dengan titonia yang mempunyai kandungan $\mathrm{N}$ dan kadar air yang tinggi. Setelah bulan ke tiga sangat dimungkinkan proses pelapukannya masih berjalan lanjut, sehingga jumlah pemberian yang sama dengan titonia hasilnya untuk 3 bulan pertama berbeda.

\section{KESIMPULAN}

Berdasarkan hasil penelitian dapat disimpulkan bahwa:

1. Pemberian beberapa jenis bahan organik dapat meningkatkan kandungan bahan organik tanah tropudult Limau Manis. Tithonia lebih cepat merespon peningkatan kandungan BO tanah, lalu diikuti oleh petai cina, kemudian baru jerami padi dan alang-alang.

2. Kandungan $\mathrm{BO}$ tanah meningkat dari $3.20 \%$ menjadi $4.75,4.65,5.27$, dan 5.51 setelah 3 bulan setelah pemberian titonia, jerami padi, alang-alang, dan petai cina, secara berturut-turut.

3. Persentase agregat mengalami peningkatan setelah 3 bulan pemberian BO. Peningkatan aggregasi $16.8 \%$ dengan titonia, $6.9 \%$ dengan jerami padi, $14.1 \%$ dengan alang-alang dan dengan petai cina

4. Indeks kemantapan agregat seluruh perlakuan selalu meningkat sampai bulan ketiga. Peningkatan tertinggi dijumpai pada pemberian titonia

\section{DAFTAR PUSTAKA}

Fiantis, D. 2004. Morfologi dan klassifikasi tanah. Jurusan Tanah. Fakultas Pertanian Universitas Andalas. Padang. 156 hal.

Fitrisia, L. (2004). Klasifikasi tanah dan evaluasi kesesuaian lahan untuk tanaman kelapa sawit, gambir dan jati pada kebun percobaan Fakultas Pertanian Universitas Andalas. Skripsi Sarjana Pertanian, Padang, 103 hal. 
Hardjowigeno, S. 1987. Ilmu tanah. Akademika Pressindo. Jakarta . 286 hal

Imbang, I. N D. R.., A, Rasyidin, Adrinal. L. Maira, dan Hermansah, 1994. Klasifikasi tanah kebun percobaaan fakultas pertanian universitas andalas di limau manis kotamadia padang. Laporan Pernelitian OPF. Lembaga Penelitian Universita Andalas. 50 hal.

Jama.B.A., C.A. Palm., R.J.Buresh., A. I. Niang., C. Gachego., G. Nziquheba and B.Amadado. 2000. Tithonia Diversifolia as a green manure for improvement of soil fertility in western Kenya. Review.Agroforestry Systems.

Nedrawati. 2006. Pengaruh pemberian bokasi tithonia diversifolia terhadap perubahan beberapa sifat fisika
Ultisol Limau Manis. Skripsi Fakultas Pertanian. Universitas Andalas. Padang. 59 hal.

Subagyo.H., N. Suharta., dan A. B. Siswanto (2000).Tanah-tanah Pertanian di Indonesia. Dalam Sumber daya Lahan Indonesia dan Pengelolaannya. Pusat Penelitian Tanah dan Agroklimat. Balitbangtan Deptan.Bogor.hal 21-66.

Yulnafatmawita. 2004. Effects of land use change on soil organic matter status of bulk and fractionated soil aggregates. Stigma Sci.J. Vol XII(2): 417:421

Yulnafatmawita. 2006. Hubungan antara status C-organik dan stabilitas aggregat tanah Ultisol Limau Manis pada Beberapa penggunaan lahan. Solum J. Vol III N0.1 J an 2006. 